\title{
Implications of Digitalization in Banking Sector: A Review of Literature
}

\author{
Rajendra Kumar Meena \\ ${ }^{1}$ M.A. (Eco.), University of Rajasthan, Jaipur, India
}

\begin{abstract}
Abstract:

This paper audits the hypothetical writing on the development of advanced and data innovation in the Indian financial industry. The awesome headways in advanced innovation have changed the manner in which banks work. The beginning of the time of computerized business has been disturbing the business condition and breaking out creative and solitary methods for working together. Probably the most recent result of this is advanced banking. Computerized banking advances have heightened throughout the years, with the accessibility of a huge arrangement of items, for example, stores, ATMs, charge cards, portable installments, and such. There is a huge probability of utilizing the framework of the advanced age to make openings - both nearby and worldwide. The expansion in rivalry and different difficulties in the financial area are pushing the banks to receive new advanced models that present one of a kind wellsprings of significant worth to them. This paper looks at the degree and the heading of the impact of advanced innovation in the space of Indian banking.
\end{abstract}

Key Words: Digital, innovation, banking, digitalization, India

\section{Introduction}

The world has been shocked by the fast propels in innovation in the course of recent decades. It has contacted and has left a permanent imprint on everything and anything that people can understand. There are multitudinous occurrences of innovation making and breaking lives and organizations - one of these being the matter of banking. The interruption of computerized innovation into the circle of banking has achieved a change in outlook in banking - making what is presently alluded to as Digital Banking.

In a wide sense, computerized banking alludes to the work of innovation to direct financial exchanges in a smooth way. It, in this manner, incorporates web based banking, electronic banking and versatile banking-the terms that are of regular use. As opposed to conventional banking, computerized banks target creating versatile advanced items and administrations to address the issues of their computerized clients. While customary online banks use pre-structured programming to build their compass, nearness and react to client needs, computerized banks use IT specialists to comprehend and appreciate their clients, and plan their items in like manner. Obviously, the imbuement of innovation has now turned out to be essential for any industry, and lingering behind can have extreme repercussions. Grasping the test is the thing that an industry should go for, particularly when that industry is exceptionally reliant upon its customer base. The point of this paper is to inspect the degree and the bearing of the impact of advanced innovation in the area of Indian banking. A broad survey of applicable writing accessible in diaries, papers, and research articles has been attempted, alongside information and data from auxiliary sources such web journals and locales.

The design of the paper is as per the following: Section II gives experiences into the development of innovation in the financial segment in India, and the advanced change that pursued. Segment III illuminates the extent of advanced banking and the ground that it covers. Segment IV and V look at the point of view of banks and clients, individually, here. The difficulties looked by India in adjusting its financial division to the quirks of innovation have been featured in segment VI. At last, segment VII gives the finishing up comments.

\section{Evolution and computerized change of the financial area}

The time of 1990s, in India, was damaged by different money related changes. These alongside globalization and advancement realized fantastic changes in India's matter of fact condition, which included banking. For an unassuming beginning, Reserve Bank of India set up a panel led by the then RBI Governer, Dr. C. Rangaranjan. With an attention 
on client administration, the board of trustees drew up an arrangement for computerization and automation in the financial business for the time of 1985-89. When the essential involvement in computerization was increased, a second Rangaranjan advisory group was shaped in 1988 so as to get ready for the augmentation of mechanization to different regions like subsidizes move, email, BANKNET, SWIFT, ATMs, Internet banking and so on. Thusly, in the year 2000, the Government of India authorized the Information Technology Act, 2000 so as to give legitimate acknowledgment to electronic exchanges and different methods for electronic business. 1996-98 was the time of Internet banking reception. After ICICI, Citibank, Indus Ind Bank and HDFC Bank were the mid ones to receive the innovation in 1999. Save bank of India set up a 'Working Group on Internet Banking' to look at changed parts of web banking. Beginning web saving money with basic capacities, for example, giving data about financing costs, financial records adjusts and registering credit qualification, the banks in the end stretched out their administrations to online bill installment, move of assets among records and money the executives administrations for corporates. This was trailed by help of installment for web based business exchanges, by legitimately charging financial balances or through Mastercards.

A high infiltration of cell phones and web associations, combined with an inclination for nonbranch banking channels, just as appearance of guidelines in this segment has realized a good move in the buyer conduct, demonstrating that a time of head computerized banking is drawing closer. Conventional banks in India have been believed to pursue certain phases to achieve the computerized change. They began with structure new money related items just as channels, for example, cell phones, so as to react to new challenge. This has been trailed by a push to reengineer the innovative foundation, for example, the installment stages, to make them progressively adaptable and easy to use. In conclusion, so as to position themselves in the computerized condition, they have received manageable systems incorporating changes and interest in their associations.

India is currently observing an ascent in the quantity of computerized shrewd youth, who are as of now quiet with taking care of their cash, funds and banking exchanges in a virtual way. As this age develops, advanced banking is certain to observe a lift.

\section{Scope of computerized banking}

Computerized banking isn't just confined to utilizing web to access banking administrations, as is typically seen, however it involves an entire exhibit of

\section{ISSN 2455-6378}

banking administrations conveyed or expended utilizing innovation. Henceforth, with a wide scope, computerized banking incorporates the accompanying:

1. Internet Banking: The web is an amazing medium and is utilized by banks to give administrations at various levels. This incorporates giving fundamental data about the different items and administrations of the banks, speaking with the clients in regards to their record adjusts or credit applications and enabling the clients to embrace exchanges, for example, installment of charges, move of assets and so forth, utilizing the web.

2. Mobile/Phone banking: Phone banking enables a client to convey and give straightforward directions to the bank using their versatile keypads, on a cell gadget. It enables them to store a check, move reserves, pay charges, realize the record balance, find an ATM or get data about their record's action.

3. Automated Teller Machines (ATMs): ATMs were the main understood machines to give electronic access to clients. These machines empower a client to perform undertakings, for example, money withdrawal, and enquire about record balance, without the assistance of a bank agent. The more mind boggling machines likewise enable clients to print their passbook, store money and access a credit extension.

4. Plastic Cards: A plastic card issued by a bank to its client can be as a Credit card, Debit card or Smart card. These cards improve the way toward causing installments at purpose of offer, to give simple access to credit to a specific timeframe or can perform different kinds of pre-characterized monetary exchanges, separately.

5. Electronic Clearing Service (ECS): Repetitive and intermittent installments are basically attempted electronically through ECS. It is utilized by foundations for making mass installment of sums towards circulation of profit, intrigue, pay, benefits, and so forth., or for mass accumulation of sums towards phone/power/water duty, cess, and so forth.

6. Electronic reserve move: Electronic store move frameworks are devoted towards 
exchange of assets inside a budgetary organization or among numerous foundations, without the association of the bank staff. Such an exchange happens over a modernized system.

7. PC/House banking: PCs outfits clients to collaborate with their bank by methods for a PC with a dial-up modem association with the telephone organize. Be that as it may, it includes complex establishment systems and support costs.

\section{From the point of view of banks}

Innovation gives a chance to banks to manufacture new models and stages that can adjust to the need of the clients. Banks comprehend that it's not just about the unpredictability and assortment of client needs, however clients are currently requesting administrations that are redone to their needs. Likewise, they don't avoid changing their banks, if these necessities are left unfulfilled. This calls for banks to turn out to be progressively delicate, mindful and pertinent to clients, by expanding their interchanges, yet by giving the correct administration at the perfect time and spot. As indicated by Chen, HV and Lam (2014), banks in India and in real pieces of Asia utilize three methodologies to position themselves in the advanced condition. These are (I) Branch driven, item engaged model, which spotlight on their conventional model, and enhancements it with direct channels to give serene administrations to clients, (ii) Multichannel customer driven model, which uses both, physical branch channel just as immediate channel-which is simply the most well known among banks, and (iii) Self-coordinated computerized driven model, that depends on inventive direct channels for deals and uses a corresponding light physical nearness for client obtaining the model which is embraced by driving computerized banks. It is for the banks to choose which mechanical model to embrace to fulfill their clients.

\section{Advantages to the bank}

Utilizing advanced intends to give administrations is in light of a legitimate concern for banks. It decreases the working expenses by curtailing office activities, limits blunders, and cuts down the quantity of hands required for tasks. It empowers a bank to cut back it branch systems, and offer administrations in a creative and alluring way. This gives a lift to the administration quality, conveyance and effectiveness, which may go about as a wellspring of upper hand to banks utilizing computerized innovations. By evacuating land impediments, it prepares for augmentation of tasks of little banks. No solitary this, yet advanced innovation has supported banks in expanding the pace of information accumulation, the executives, and monetary building, consequently improving the capacity of loan bosses to survey the financial soundness of potential borrowers. Different examinations have demonstrated that because of increment in innovation use, the financial segment's exhibition builds step by step.

\section{Impediments to going computerized}

Persistent adjustments in the outer condition of the bank-through globalization, progression and deregulation-have prompted augmentation of competition in the area. Only focussing on their expenses is no more the stunt, however captivating and holding the clients is. Mia, Rahman and Uddin (2007) connected the Porter's Five Forces Model of Competition, so as to check how profitable the computerized part is for the banks. This model is relevant for the Indian financial part also. To begin with, taking up the degree of contention among the current players, there is no single 'unadulterated' computerized bank in India. Be that as it may, banks are exceptionally focused as in they are quickly abusing innovation to give different administrations on the web and electronically, without settling on the quality. To the extent obstructions to passage are concerned, they are high a direct result of the way that specific banks in India that have an immense client base and devotion, and consequently have upper hand over new participants. Hitting on providers, which comprise of the product suppliers if there should be an occurrence of a financial industry, nearness of a couple of enormous players builds their bartering power. Simultaneously, the dealing intensity of purchasers, that is the clients, is expanding because of regular changes in client demeanors, bringing down of changing expenses and rivalry from non-banking organizations. Finally, the danger of substitutes to banking as far as rivalry from the non-banking, budgetary, and miniaturized scale credit area is rising. The limits that used to exist among banking and non-banking as far as administrations are presently diminishing. This is clear in the manners in which telecom organizations, for example, Reliance Jio, just as Fintech new businesses, for example, Paytm is offering advanced money related administrations to their clients. In spite of the fact that the above investigation demonstrates how extreme it is for any new bank or monetary specialist organization to embrace computerized innovation in the light of rivalry, yet with the correct mix of thoughts and long haul technique, one can most likely position itself in this division.

As is clear, there are various techniques and models that can be embraced by banks. Be that as it may, with regards to India, 'Web just' models have fizzled. The present pattern is 'Block and Click' or 'Snap and 
Mortar', wherein banks join physical nearness with web and electronic channels.

\section{From the point of view of the clients}

Bank clients are never again not well educated, however they realize how to ensure their interests. They effectively switch between banks in the event of any disappointment with the administrations. According to an examination led by Rao and Budde (2015), 67\% of Indian clients want to connect with their bank through various channels. Be that as it may, these channels don't supplant each other yet rather expand the manners by which a bank can connect with its clients. Another investigation by Srivastava (2007) uncovered that statistic factors, for example, salary, sex, training levels have a significant impact on the readiness of clients to go for advanced banking. It was additionally recommended that improving the mindfulness, mechanical education and aptitudes of clients would confine the capacity of these elements to obstruct the utilization of on the web and electronic financial administrations.

In addition, simply having an online presence isn't what the clients of advanced banking are searching for. What they need comprises of (I) predominant worth and great quality fundamental administrations, (ii) a solid brand notoriety, (iii) the range, assortment, aggressiveness of budgetary items offered, and (iv) a high responsibility to client administrations, need, complaints and positive experience.

\section{Advantages to Customers}

The real turn-on of innovation based banking gets from the 'whenever, anyplace accessibility' of banking administrations. These outcomes in comfort to clients as well as huge decrease in time and exertion included. What pursues is a decrease in expense of benefiting administrations, just as persistent access to data. Mechanization of banking administrations additionally encourages recordkeeping of one's exchanges, deserting a money related trail that can be effectively followed. For organizations and firms, it supports better finance the board, and gives access to different administrations in a hurry, along these lines expanding productivity. Various new administrations, for example, alerts, warnings, planning are additionally a result of computerized. Because of expulsion of time constraint, land impediment and cost restrictions, computerized banks by and large have a high ground over branch-based banks.

\section{Client Concerns}

A move towards computerized banking does not demonstrate a ruin of the branch-based banking.

\section{ISSN 2455-6378}

Branch systems would keep on being appropriate, except if the different worries that frequent clients are discarded. The serious issue is security and wellbeing of executing utilizing the web. Occurrences of wholesale fraud, loss of private data and abuse of delicate information are not small going about as a damper to utilization of innovation particularly among hazard dreading clients. Utilization of electronic intends to lead exchanges removes the capacity of clients to have an individual associate with brokers and look for counsel on confounded items and administrations. Simultaneously, some accept that the online items in themselves are intricate to the point that they need somebody to disclose the use to them-production manual banking appear to be increasingly advantageous and adaptable. Numerous multiple times, these administrations might be hard to access, for instance, due to non-accessibility of ATMs in a specific territory, or no web availability, and the expenses charges for the exchanges are seen by certain clients as being preposterous.

\section{Challenges in execution}

India faces certain impossible to miss obstacles which repress the development of computerized banking in the nation. The real ones are:

- A nation requires a satisfactory degree of framework so as to embrace the innovation and give the fundamental help to its development and utilization. Notwithstanding, the foundation in India is still as an incipient stage. Web network is yet to arrive at many.

- Since the web is an open wellspring of correspondence, protection and security of information moved over the system is defenseless to robbery, unapproved access and abuse. Cybercrimes and hacking is a major reality in India and even the most believed firms are not sheltered from it. This has prompted a decrease in trust on advanced exercises of banks.

- Although the financial segment in India is profoundly controlled as far as capital sufficiency necessities, provisioning and resource acknowledgment standards, ventures, chapter 11 standards, and so forth yet it is hard to stretch out these rules to computerized banks. In spite of the fact that $\mathrm{RBI}$ is thinking of structures for explicit exercises, (for example, giving NBFC status to distributed loaning stages), anyway these administrative standards are yet to be characterized unambiguously and executed convenient. Likewise, certain guidelines, for example, KYC prerequisites, warrant 
individual contact and eye to eye gatherings between the investor and client, which may not be conceivable if there should arise an occurrence of an unadulterated advanced bank

- Technological blast in the financial segment has prompted new sorts of items/administrations and better approaches for conveying them. In any case, these require different extra legitimate definitions, for example, which means of electronic mark, and consents. Simultaneously, existing lawful definitions and authorizations are additionally required to be reconsidered.

The administration, and private area need to meet up to take care of the holes so as to guarantee that the fantasy of genuine digitization turns into a reality for India. Ceaseless endeavors as safety efforts, mindfulness battles, computerized education, infrastructural speculation, and so forth - would need to be depended on, in order to abuse the maximum capacity of innovative improvements.

\section{Conclusion}

There are relatively few developments that have changed the matter of banking as significantly as the innovative upset. Banks in various pieces of the world are patching up their long haul systems so as to tackle the open doors offered by digitization. It isn't amazing that the financial business was one of the absolute first to use data innovation, thinking back to the 1960s, and has along these lines a record of impacting the advancement procedure through innovation.

The survival and achievement of a 'web just' model or a 'unadulterated' advanced bank is distressing in India. Not in light of the absence of market, but since 'block and concrete' branches give the Indian clients, particularly the matured age, a feeling that all is well with the world and certainty. Subsequently, in spite of the intrigue of computerized offers, banks need to adjust their conventional physical nearness with advanced nearness. The job of the Indian government in giving a helpful situation to encourage uplifting frame of mind among clients, is additionally key. Simultaneously, conventional banks should wake up and understand that they are never again the sole players in the business, and that the new contestants, as fintech new companies, have a great deal to offer to a digitalized customers, and that them two can accomplish a success win circumstance by working together, as opposed to contending, with each other.
Finally, Indian banks need to manage the conceivable negative results of computerized disturbance on their incentive by animating advanced mindfulness and accomplishing minimum amount which would eventually prompt verbal advancement.

\section{References}

[1] Barquin S, Vinayak HV. Digital Banking in Asia: What do consumers really want. McKinsey and Company.

[2] Chavan J. Internet banking-Benefits and challenges in an emerging economy. International Journal of Research in Business Management. 2013; 1(1):19-26.

[3] Chen J, Lam K. How to prepare for Asia's digital- banking boom. McKinsey and Company.

[4] Cuesta, C., Ruesta, M., Tuesta, D., \& Urbiola, P. (2015). The digital transformation of the banking industry. BBVm Research.

[5] Gautam L, Khare SK. E-Banking in india: Issues and challenges'. Scholar Journal of Economics, Business and Management. 2014; 1(2):54-56.

[6] Mia MAH, Rahman MA, Uddin M. EBanking: Evolution, Status and Prospect. Journal of the Institute of Cost and Management Accountants of Bangladesh. 2007;35(1):36-38.

[7] Rao YV, Budde SR. Banking technology innovations in India: Enhancing customer value and satisfaction. Indian Journal of Science and Technolog

[8] Acharya Viral V, Thomas Cooley, Matthew Richardson \& Ingo Walter (2011). "Market Failures and Regulatory Failures : Lessons from Past and Present Financial Crises," Finance Working Papers 23273, East Asian Bureau of Economic Research.

[9] Cosimano, T. F., \& Haura, D. S. (2011). Bank behaviour in response to Basel II: a cross country analysis. Working paper 11/119, International Monterey Fund.

[10] Fratianni Michele \& Francesco Marchionne (2009). "The Role of Banks in the Subprime Financial Crisis," Working Papers 2009- 02, Department of Business Economics and Public Policy, Kelley School of Business, Indiana University.

[11]FSA-Financial Services Authority (2009). The Turner Review: A Regulatory Response to the Global Banking Crisis. 
[12] Kiema, I., \& Jokivoulle, E. (2010). Leverage ratio requirement and credit allocation under Basel III. Department of Economics Discussion paper 645, University of Helsinki Finland.

[13] Reddy, Y. V. (2009). India and the Global Financial Crisis: Managing Money and Finance. New Delhi: Orient Blackswan.

[14] Safeena R, Date H, Kammani A. Internet Banking Adoption in an Emerging Economy: Indian Consumer's Perspective. Int. Arab J. e-Technol. 2011; 2(1):56-64.
[15] Singh B, Malhotra P. Adoption of Internet banking: An empirical investigation of Indian banking Sector. The Journal of Internet Banking and Commerce, 1970, $9(2)$.

[16] Srivastava RK. Customer's perception on usage of internet banking. Innovative Marketing. 2007; 3(4):67-73.

[17] Storming the banks Banking Tech, 2016. 